\title{
Ponytail
}

\section{Michael Crane}

I was appalled at my friend Paul's trophies hanging on the walls of his flat.

'You have to stop doing this,' I told him. 'It's not healthy. Actually, it's quite sick.'

'I can't help it.' Paul replied, 'I've never felt so alive.'

'Maybe, but it's at the expense of innocent women', I said.

Paul scoffed at me. 'That's a bit naïve, there isn't such a thing as an innocent woman. They all crave vengeance and power.'

He adjusted the rubber band around his ponytail that he had worn since his university days when we both studied law together at the End of the World.

'Well I'm taking the power away from them. Beauty gives them more power, Paul said, and gestured at the walls of his flat where more than a hundred womens' ponytails were hanging. Each ponytail 
had a cardboard plaque beneath it indicating which woman they belonged to and where he had stalked them and crept up behind them and cut off their hair. There were different coloured ponytails, including some that had obviously been dyed.

Paul had been a tough barrister but since his wife divorced him he had become bitter towards women.

There was a knock on the door. Paul opened it and standing there was a tall woman with short blond hair holding a pair of shears. She burst into the room and put her arm around Paul's neck and began to shear off his ponytail. She was quite a strong woman and she didn't need my help to hold Paul down, besides, I was in too much shock. I began taking the ponytails off the walls. I figured it was the least I could do. 